\title{
Firm Responses to Mass Outrage: Technology, Blame, and Employment
}

\author{
Vikram R. Bhargava ${ }^{1}$
}

Received: 6 December 2017 / Accepted: 12 October 2018 / Published online: 26 October 2018

(c) The Author(s) 2018

\begin{abstract}
When an employee's off-duty conduct generates mass social media outrage, managers commonly respond by firing the employee. This, I argue, can be a mistake. The thesis I defend is the following: the fact that a firing would occur in a mass social media outrage context brought about by the employee's off-duty conduct generates a strong ethical reason weighing against the act. In particular, it contributes to the firing constituting an inappropriate act of blame. Scholars who caution against firing an employee for off-duty conduct have thus far focused primarily on due process related issues or legal concerns pertaining to free speech, lifestyle discrimination, and employment at-will. However, these concerns amount to only a partial, and contingent, diagnosis of what is at issue. I argue that even when due process considerations are met, firings in these contexts can be unjustified. Moreover, even if a business is not concerned with the unethical conduct per se, but is rather strictly concerned with PR, the argument I advance nevertheless provides one important ethical reason that counts against firings in mass social media outrage contexts. Given that managers are often under significant pressure to respond swiftly in cases where an employee is at the center of mass social media outrage, it is especially important that scholars begin to clarify the normative issues. This article builds on the burgeoning philosophical literature on the ethics of blame and provides a novel account of a distinctive ethical concern that arises with firings in mass social media outrage contexts.
\end{abstract}

Keywords Firing $\cdot$ Blame $\cdot$ Social media

\section{Introduction}

Many of us act in ways that, at least occasionally, violate standards of a social or communal nature-e.g., by breaching etiquette, flouting norms, or transgressing morality. Sometimes, these violations happen when we are away from work (Anderson 2017; Barry 2007a, b; Hill and Wright 1993; Sugarman 2003). While the fact that people violate normative standards while off-duty has been true for centuries, recent technological advances, most notably social media, have altered the ethical landscape. In particular, these advances affect how employers should respond to these violations in normatively significant ways.

This article concerns the ethics of how firms respond when an employee's off-duty conduct generates mass social media outrage. Businesses commonly respond by firing the

Vikram R. Bhargava

vbhargava@scu.edu

1 Department of Management and Entrepreneurship, Leavey School of Business, Santa Clara University, 500 El Camino Real, Santa Clara, CA 95053, USA employee. Several such examples follow. Shortly before taking off from Heathrow International Airport to spend the holidays with her family in Cape Town, a woman tweeted from her personal Twitter account: "Going to Africa. Hope I don't get AIDS. Just kidding. I'm white!" (Ronson 2015a, p. 68). While airborne, unbeknownst to her, the tweet went viral and generated mass social media outrage; her social media and email accounts were flooded with condemnatory messages. At the time of her tweet, the woman was 30 years of age and a senior director for corporate communications for an Internet and media holding company. In the month prior to her tweet, her name was searched on Google thirty times. In the 10 days following her tweet, that same name was searched 1,220,000 times (Ronson 2015a).

Before her flight had landed, her employer announced, "This is an outrageous, offensive comment that does not reflect the views and values of [our company]. Unfortunately, the employee in question is unreachable on an international flight, but this is a very serious matter and we are taking appropriate action" (Coine and Babbitt 2014, p. 29). 
She was fired within a day. ${ }^{1}$ This scenario (let's call it the "AIDS-tweet case") is an example of the sort of phenomenon this article is about. And the example is far from isolated.

In another scenario, a developer evangelist in the audience at the PyCon 2013 tech conference overheard a conversation between two friends in the row behind her (Ronson 2015a). She covertly photographed the two, and without their knowledge or consent, tweeted the photo with the following caption: "Not cool. Jokes about forking repo's in a sexual way and "big" dongles. Right behind me \#pycon." The tweet quickly gained attention on social media and generated mass outrage. One man in the photograph was fired from his job as a developer the following day.

But the story does not end here. Once Internet users learned of the firing, a second bout of mass social media outrage erupted, this time aimed at the woman who tweeted the photograph. She was subjected to vicious remarks, including rape and death threats. As it turns out, she too was fired from her job, in part for "publicly shaming the offenders" (Tune 2013). (Let's call this the "Dongles case").

The issue of firings in response to mass social media outrage is not unique to the United States. In 2016, an Australian expat, frustrated that the Pokémon Go smartphone game was not yet available in Singapore, tweeted, "you cant catch pokemon in this fucking piece of fucking shit country." Outrage erupted and he was subsequently fired from his role as a search engine optimization consultant. ${ }^{3}$ Nor is the issue restricted to white-collar jobs and organizations. A 22-year-old carpenter posted remarks to his Facebook that appeared to support the riots that followed the 2011 Stanley Cup in Vancouver including, "atta boy vancity!!! show em how we do it!!!" and "vancouver needed remodeling anyway...." ("Man fired for applauding Vancouver riot on

\footnotetext{
${ }^{1}$ In the weeks that followed the employee's tweet, she shortened her stay in South Africa because employees of the hotel she was lodging at threatened to riot, and authorities told her that they could not guarantee her safety. Once she returned to New York, journalists followed her around the city. Others placed her life prior to the tweet under a microscope, unearthing social media activity from years and months prior to expose other cringeworthy tweets. It is worth noting that she was previously an unknown PR person with 170 followers on Twitter. Relatively speaking, she had an insignificant social media presence and was not a public figure. See Ronson's (2015a).

2 Some terminological clarifications may help. In tech lingo, "to fork" means to copy, "repo" is software, and a "dongle" is a connector device. In tech circles it is commonly considered flattering to take another person's software and build on it oneself; "forking a repo" is a common locution to refer to this process (Ronson 2015a).

3 The man fired in the Pokémon incident was fired only a week into the job. I am open to the possibility that the duration of the relationship with the employee can be of moral significance. This might mean, for example, that firing an employee who generates mass social media outrage after his or her first day on the job is less problematic than firing someone who has had a more extended tenure.
}

Facebook" 2011). His remarks quickly gained attention and news outlets reported that he was fired the next day from his job at a construction company. (Let's call this the "Vancouver Riots Case").

Mass social media outrage can target employees around the world and in a variety of organizations. Thus far, little philosophical attention has been devoted to the ethics of firing an employee for off-duty conduct, with notable exceptions being work by Anderson (2017) and Barry (2007a, b). Some legal scholars who have written about off-duty conduct have done so within the context of lifestyle discrimination (Hill and Wright 1993; Sugarman 2003). Unfortunately, these scholars provide little in terms of ethical argument for the distinctive wrongness of firing an employee in response to mass social media outrage brought about by the employee's conduct. The ethics of how managers should respond when an employee is at the center of a social media storm is ripe for investigation.

In this article, I defend the following thesis: the fact that a firing would occur in a mass social media outrage context brought about by the employee's off-duty conduct generates a strong ethical reason weighing against the act. In particular, it contributes to the firing constituting an inappropriate act of blame. To arrive at this thesis, I defend the following premises:

1. The firing claim Firing an employee in a mass social media outrage context brought about by the employee's off-duty conduct constitutes an act of blame.

2. The dependence principle The appropriateness of an act of blame depends in part on how much others blame.

The first is a claim unique to organizational contexts. The second is a general principle relevant in any instance when one is blaming another, but it is especially salient in contexts where mass social media outrage is directed at employees.

In making this argument, I appeal to the burgeoning philosophical literature on the ethics of blame (Cohen 2006; Fricker 2016; Friedman 2013; Hieronymi 2004; Radzik 2011; Scanlon 2008; Sher 2006; Smith 2007; Wallace 1994; Watson 2013). The blame literature has been useful for a wide range of scholarly investigations including, rights theory, forgiveness and apology, the free will debate, and the philosophy of punishment. Moreover, the topic of blame has drawn the attention of businesspeople, as seen in such

\footnotetext{
${ }^{4}$ As of the date of submission, the man who was fired still appears on the website of the construction company from which he was reportedly fired. It is not clear whether he was (a) rehired, (b) news outlets misreported the case and that he was never in fact fired, or (c) that the website is not up to date. Neither the man who was reportedly fired, nor the president of the company, responded to email inquiries about this matter.
} 
popular articles as "How to Stop the Blame Game" in the Harvard Business Review (Fast 2010), "Blaming Others: The Slow Way to Kill Your Business" in Inc.com (Sherman 2014), and "The Workplace Whodunit: Navigating a Culture of Blame" in the Wall Street Journal (Donner 2011). Yet a normative analysis of blame practices in business has received scant attention from business ethicists. ${ }^{5}$ For decades now, much of the scholarly conversation in employment ethics has centered around whether the theoretical foundations undergirding property rights, contracts, or autonomy can help justify employment at-will, the legal presumption that employers can terminate an employee for good reason, bad reason, or no reason, with or without warning (Epstein 1984; Maitland 1989; McCall and Werhane 2009; Werhane et al. 2008). ${ }^{6}$ I suggest that exploring the blame literature will allow employment ethics scholars to move beyond this well-trodden debate and can provide the tools for entering new theoretical terrain in the employment realm.

While the topic of how to respond to employee conduct that generates mass outrage is undertheorized, this may be because many have the sense that what is primarily at issue is a disregard for due process (roughly, the right to a hearing in the face of potential sanctions) and procedural justice (roughly, the issue of whether the outcome of a given decision, including sanctioning decisions, was arrived at using fair procedures). The topic of procedural justice has received extensive attention in management scholarship (Bianchi and Brockner 2012; Bies and Shapiro 1988; Bobocel and Gosse 2015; Brockner 2002; Brockner et al. 1994, 2005; De Cremer et al. 2010). Though this literature is important, it largely focuses on employee perceptions of justice and thus fails to engage with the normative dimensions of procedural justice and due process. Although some philosophers and business ethicists have discussed due process and procedural justice in a normative context (McCall and Werhane 2009; Radin and Werhane 1996; Scanlon 1977; Werhane 1999; Werhane et al. 2008), in the view I argue for, violations of procedural justice and due process are only a partial, and contingent, diagnosis of what is at issue with firings in mass outrage contexts. This article highlights the fact that even when firms uphold the requirements of procedural justice

\footnotetext{
5 A notable exception is recent work by Lupton and Warren (2018). As they aptly note, "there are insights to be gained from applying philosophical ideas to the subject of blame in organizations" (2018, p. 47).

${ }^{6}$ Similarly, employees can quit with or without reason and with or without warning. There are certain exceptions to employment at-will, namely, the constitutionally protected classes: race, gender, sexual orientation, and so on (Bennett et al. 1998). Interesting philosophical questions arise with regard to the symmetrical nature (or lack thereof) of the employment relationship (e.g., is it permissible for an employee to quit a job due to a manager's off-duty immoral conduct?).
}

and due process, this does not exhaust the ethical constraints a manager faces in mass social media outrage contexts. Previous perspectives in employment ethics do not satisfactorily account for how the context in which a firing occurs can affect the morality of the firing and how recent technological advances, notably social media, can help bring about these very sorts of morally significant contexts.

It is worth discussing some of the ways in which technological advances affect the ethical landscape and why these advances should bring us to revisit questions pertaining to the ethics of firing and blame. First, at no other time in history could the critical scrutiny and blame of millions of individuals fall upon any other member of society, located nearly anywhere in the world, within moments. This alone has the power to dramatically alter how communities uphold and respond to ethical and social norms. We thus ought to consider how these developments enabled by social media affect the ethics of certain business decisions, including firing decisions.

Second, even in cases where the wrongdoer has been misidentified, or where further investigation reveals that no misconduct has occurred or that the misconduct was plausibly excusable, there is little accountability on the part of the individuals who contributed to the mass social media outrage. In the past, those who mistakenly blamed another may have felt the awkwardness and discomfort of encountering the person face-to-face, or they may have suffered the embarrassment of having mistakenly cast aspersions on a member of their community; some may even have been moved to apologize to the mistakenly accused person. Social media, however, allows us to blame a person whom we have never encountered and need not ever encounter; if we mistakenly blame that person, we can simply delete the post from social media and never acknowledge the person. In other words, social media has lowered the costs associated with blaming an individual, but it remains (at least) as personally burdensome to be the target of blame.

Third, in countries without a legal "right to be forgotten" (Grierson and Quinn 2018) including the United States, after an employee is subjected to a bout of mass social media outrage, a permanent and easily accessible record of this occurrence remains on search engines. This means there may be no such thing as a fresh start for those who were once at the center of mass social media outrage. Many employers, university admissions committees, and even prospective romantic partners investigate the internet presence of an individual before deciding to associate with that individual (Bhardwaj 2017; Langston 2012; Root and McKay 2014). In the past, if one was blamed by one's community for some alleged misconduct, one had the opportunity to recreate oneself, as it were, perhaps by moving, changing jobs, or waiting until others had forgotten about the misconduct. This is now much more difficult. 
Fourth, because many businesses also have active social media presences, the alleged misconduct that generates the episode of mass social media outrage will undoubtedly be brought to the attention of the employer, either intentionally (e.g., the employer is "tagged" in a social media post) or otherwise. As such, even if the alleged misconduct is not at all related to the day-to-day operations of the business, the business must contend with it. This makes it difficult for firms to remain ignorant (willfully or otherwise) about an employee's off-duty conduct.

Fifth, while consumer advocacy organizations and boycotts of firms for mistreating workers, suppliers, or the environment are not new phenomena, social media allows large numbers of individuals to quickly organize and place significant pressure on managers to make particular employment decisions in a way that is unprecedented. Indeed, there are now websites dedicated to drawing the attention of employers of persons who act in allegedly untoward ways and enlisting individuals on social media to demand that the employer fire these employees (e.g., the Tumblr website, "Racists Getting Fired"). Social media allows thousands of individuals to quickly coordinate and flood corporate email accounts, phones, and social media with demands to fire an employee, thereby placing considerable pressure on managers to make particular employment decisions, a realm of decision-making once largely insulated from such pressures.

To summarize, technological advances, most notably social media, have brought about an asymmetry with respect to the ease with which large numbers of people can come together to blame an individual in a way that was never previously possible, without a comparable reduction in the onerousness of being the one subjected to blame. This fact alone has the power to transform the way social norms and morality are enforced and sanctioned; for this reason, the role of business in relation to these developments merits scholarly attention. Jon Ronson's characterization of blame on social media seems apt: when blame is "delivered like remotely administered drone strikes, nobody needs to think about how ferocious our collective power might be. The snowflake never needs to feel responsible for the avalanche" (Ronson 2015a, p. 56). Given that managers are often under significant pressure to respond swiftly in cases where an employee is at the center of mass social media outrage, it is especially important that we begin to clarify the normative issues. This article brings the latest philosophical research on blame to bear on a practical problem of managerial relevance.

A brief roadmap is in order: In "Boundary Conditions, Scope, and Current Work on the Ethics of Firing," I offer some preliminary remarks then situate the argument in the employment ethics conversation by discussing the relevance of employment at-will and due process. In "How Do Mass Social Media Outrage Contexts Affect the Ethics of Firing?," I present the core argument: I first support the premise that firing an employee in a mass social media outrage context constitutes an act of blame ("The Firing Claim") and then I argue that not only is the firing an act of blame, but that the fact that the blaming through firing occurs in a mass social media outrage context contributes to it constituting an inappropriate act of blame ("The Dependence Principle"). In "What are Some of the Other Factors to Consider When Blaming and Firing?," I acknowledge some additional considerations that bear on the appropriateness of blame and the ethics of firing beyond those raised by my argument. In the section after that, I offer some reflections directed at those who insist that the business ought to fire the employee. I then briefly discuss some ways through which a business might respond in lieu of firing. In the penultimate section I discuss some of the implications of this work and some future avenues of research. I then conclude.

\section{Boundary Conditions, Scope, and Current Work on the Ethics of Firing}

\section{Boundary Conditions and Scope}

Before moving forward, three points of clarification are in order. First, there are manifold reasons that may ground a decision to fire an employee: incompetence, disloyalty, cost, redundancy, disagreeability, malingering, and so on. Identifying which reasons (or combination of reasons) provide decisive justification to dismiss an employee would require developing a comprehensive theory of firing. The task I take on is more modest: I am concerned with how the fact that a firing would occur in a mass social media outrage context brought about by the employee's off-duty conduct affects the ethics of the firing decision. (Hereafter, for expository purposes, when I write "firing in a mass social media outrage context," it should be understood to be short for "firing in a mass social media outrage context brought about by the employee's off-duty conduct"). I acknowledge that there may be other ethical considerations, including considerations that might tell in favor of firing the employee, beyond those that my argument brings to light; sometimes these considerations might even be more ethically significant than the ones raised by my argument. This is why the thesis I defend should be understood as generating one strong ethical reason weighing against firings in mass outrage contexts, but this reason need not be one that is decisive. Still, if I am correct, the argument I present illuminates a weighty consideration against firings in mass outrage contexts that has not been adequately appreciated. 
Second, my purpose in this article is not to settle whether the kind of cases I offered at the outset in fact involve unethical conduct. ${ }^{7}$ Instead, I will argue that even if we suppose that all such cases involve unethical acts, or alternatively, if the manager thinks (perhaps mistakenly) that these acts are unethical, nevertheless, the fact that the firing would occur in a mass social media outrage context can provide one important moral consideration weighing against firing the employee. Going forward, for expository purposes, when I refer to an employee's unethical conduct, it should be understood to also include allegedly unethical conduct. Also, what matters for our purposes is not that the wrongdoing occurred on the internet, but rather that the wrongdoing, wherever it occurred, was met with mass social media outrage.

That being said, certain sorts of wrongdoings are ones that most, if not all, plausible accounts of employment ethics would recognize as generating sufficient justification to fire: these are cases in which the employee's off-duty act is also of a serious criminal sort (e.g., domestic violence, assault, possessing child pornography, child abuse, burglary, kidnapping, rape, murder, and so on) or is an act that wrongs an entire victim class through, for example, blatant sexism or racism (e.g., addressing someone using a racial slur, participating in a white supremacist rally such as the 2017 Charlottesville rally, and so on). ${ }^{8}$ I too consider these sorts of cases, as well as cases of sexual harassment, as ones where an employer is often plausibly justified in terminating the employee. This is so regardless of whether the conduct occurred on or off-duty, though the justification to fire is plausibly even weightier when the wrongdoing occurs on-duty. Moreover, this would be just as true even if the employee skirted criminal sanction due to a legal technicality. This is not to say that the

\footnotetext{
7 Note that I use "immoral," "unethical," "wrongdoing," and "misconduct" interchangeably throughout this article.

${ }^{8}$ Some readers might think that the AIDS-tweet was blatantly racist. While I find this implausible (especially in view of the examples of blatant racism I have offered), I will not get into specifying the necessary and sufficient conditions for what counts as blatant racism. For those interested in the reflections of the woman who wrote the tweet, here is a letter she penned to the South African newspaper, The Star, soon after: "Words cannot express how sorry I am, and how necessary it is for me to apologize to the people of South Africa, who I have offended due to a needless and careless tweet. There is an AIDS crisis taking place in this country, that we read about in America, but do not live with or face on a continuous basis. Unfortunately, it is terribly easy to be cavalier about an epidemic that one has never witnessed firsthand. For being insensitive to this crisis-which does not discriminate by race, gender or sexual orientation, but which terrifies us all uniformly - and to the millions of people living with the virus, I am ashamed. This is my father's country, and I was born here. I cherish my ties to South Africa and my frequent visits, but I am in anguish knowing that my remarks have caused pain to so many people here; my family, friends and fellow South Africans. I am very sorry for the pain I caused" (Otto and Sapa 2013).
}

arguments I offer are irrelevant in such cases, but rather that there are different, weightier, ethical considerations, that may dominate in such cases. ${ }^{9}$ This is why the view I defend should be understood as presenting one strong ethical reason weighing against firings in mass outrage contexts, but this reason need not be one that always defeats other ethical considerations.

Third, I assume that there was no reason to fire the employee prior to the alleged misconduct. In other words, the employer was not weighing the decision to terminate the employee prior to the act that generated mass outrage. More precisely, the justification to fire was not overdetermined, or even partially determined, by the employee's behavior prior to the act that generated mass social media outrage.

With these clarifications behind us, let us now discuss some of the current perspectives in employment ethics that relate to the present investigation. I will first touch on the issue of employment at-will.

\section{On Employment At-Will}

In the United States, the overwhelming majority of states presume employment at-will. Insofar as there is a presumption of employment at-will, some might think that a manager can fire an employee for whatever reason or even no reason (Epstein 1984; Maitland 1989). From this perspective, one might think that asking what justifies a particular instance of firing is simply out of place and confused. I offer two points in response.

First, we cannot simply presume employment at-will as a necessary feature of the employment relation just because it is currently the legal presumption in the United States. In much of the developed world, employment at-will is not the presumption. Moreover, the theoretical grounds for employment at-will have come under sustained criticism over the last several decades. Some influential critics of employment atwill have argued for certain general employee rights (McCall 2003; McCall and Werhane 2009; Radin and Werhane 1996; Werhane and Radin 1999; Werhane et al. 2008). Others have argued for certain specific rights, for example, the right to a safe work environment (Arnold 2009), privacy within and outside the workplace (Moore 2000), and the ability to freely exercise speech on political matters (Barry 2007a, b).

Second, even if we suppose that a manager has a right to fire an employee in the way employment at-will permits, there are better and worse ways in which the manager can exercise this right. Consider the following:

Campus Recruiter: Suppose a manager participates in a campus job fair and hires seven bright-eyed under-

\footnotetext{
9 Alternatively, if it is wrong to fire an employee for these more serious offenses, it may be for different reasons than those I am offering.
} 
graduates. Unbeknownst to the candidates, the manager has hired these individuals only for the pleasure of firing them the next day.

The manager's exercise of employment at-will is not plausibly well justified. There is a distinct set of ethical considerations that a manager must attend to even if there is a legal presumption of employment at-will. Insofar as there are better and worse ways in which one can exercise employment at-will, this is what is minimally needed for the present investigation to get off the ground.

\section{On Why Due Process and Procedural Justice are Not Enough}

Some might think the wrong in firing in response to mass social media outrage lies in a flagrant disregard for due process. This is plausible. There are often violations of procedural justice and due process when employers fire in response to mass social media outrage. But this, I will suggest, is not what is at the core of the issue.

It will help to first clarify the concept of due process. There are two types of due process: procedural and substantive. Roughly, procedural due process involves a right to a hearing, appeal, or other mutually agreed-upon grievance procedures (Scanlon 1977; Werhane 1999), and substantive due process involves the manager giving "good reasons for employment decisions" (Werhane 1999, p. 238). In Tara Radin and Patricia Werhane's view, "[D]ue process in the workplace is a moral requirement consistent with rationality and good managerial decision-making" (1996, p. 269), and elsewhere Werhane argues that it is a "moral minimum for fairness" (1999, p. 239).

To be clear, I do not deny that there are procedural justice or due process violations involved when a firm fires an employee in mass social media outrage contexts. On the contrary, it seems likely that there are both procedural and substantive due process violations: Procedural due process is plausibly violated because employees are often fired without having had the opportunity to share their side of the story. Moreover, given how soon after the alleged wrongdoing the employee is often fired-frequently in less than a daywe have prima facie evidence that the employee was not afforded procedural due process in any meaningful sense. ${ }^{10}$

\footnotetext{
${ }^{10}$ Recall the AIDS-tweet case. The woman's employer released a condemnatory press release before her flight had even landed. Her termination was written on the wall, as it were, before she herself realized that she was the focus of mass outrage. Given this, it seems unlikely that she was given an adequate hearing or opportunity to voice her perspective. Had she been given a hearing, what might her employer have learnt? For one, her perspective:

only an insane person would think that white people don't get AIDS...To me, it was so insane a comment for an American to make I thought there was no way that anyone could possibly think that it was a literal statement. I know there are hateful people out
}

Substantive due process is also plausibly violated: when the manager's decision to fire is grounded in information stemming from a barrage of social media posts, important contextual details will often be lost, and the manager may reason on the basis of hearsay and other epistemically corrupt sources of justification. Furthermore, a psychological bias that can incline a manager to violate substantive due process is the just-world fallacy (Lerner 1980), an inclination to think that the bad things that occur to a person must be deserved due to that person's previous untoward behavior. As a result, the manager may come to think that the mass social media outrage surrounding an employee is justified, even if the collective outrage is in fact unjustified or premised on falsehoods.

Despite the relevance of due process and procedural justice to the topic at hand, I suggest that focusing on them presents three problems. First, defenders of employment atwill who are skeptical of the notion of employee rights will not be moved by appeals to such rights. What is required is an argument that both defenders and critics of employment at-will must engage with, an argument that does not adopt premises concerning the legal justifiability of employment at-will and does not stipulate the existence of due process rights in employment.

Second, and more importantly, even when the employee is granted due process, firing in response to mass social media outrage may nevertheless be wrong. This is because respecting these rights is a moral minimum. Employee rights do not carve up the moral possibility space exhaustivelymanagers can act wrongly without violating any employee rights.

Third, firings do not occur in vacuums and our theories of employment ethics should not treat them as though they do. Certain contexts in which a firing might occur, including mass outrage contexts, can affect the firing decision in morally significant ways. Importantly, recent advances in technology, most notably social media, make it much easier

\section{Footnote 10 (continued)}

there who don't like other people and are generally mean. But that's not me...It was a joke about a situation that exists...It was a joke about a dire situation that does exist in post-apartheid South Africa that we don't pay attention to. It was completely outrageous commentary on the disproportionate AIDS statistics. Unfortunately, I am not a character on South Park or a comedian, so I had no business commenting on the epidemic in such a politically incorrect manner on a public platform. To put it simply, I wasn't trying to raise awareness of AIDS, or piss off the world, or ruin my life. Living in America puts us in a bit of a bubble when it comes to what is going on in the third world. I was making fun of that bubble. (Ronson 2015a, pp. 73-74).

Even if she had been extended procedural due process, perhaps her employer would nevertheless have deemed her remarks racist and would have fired her. But insofar as there is moral significance to procedural due process, her perspective should have been heard; this is so, even if after deliberating, her employer ultimately would have still decided to fire her. 
to create such morally significant contexts than ever before. Yet our present approaches to the ethics of firing do not adequately account for these developments.

If the account I advance is correct, then this will be a significant result: there is a distinctive ethical concern that is raised by firings in mass social media outrage contexts that is not captured by standard explanations pertaining to procedural justice or due process. The point is that even if an employee was extended due process in the form of a legitimate hearing, and the hearing resulted in the verdict that the employee did in fact act unethically (perhaps the employee even admits to the wrongdoing), this does not mean that the manager has satisfied the demands of morality and can now justifiably terminate the employee. This is because there are ways in which the manager can act wrongly beyond those associated with the requirements of procedural justice and due process. One of the ways a manager can act wrongly, as I will argue in the next section, involves violating the requirements of the ethics of blame. Crucially, the fact that a firing would occur in a mass social media outrage context would bear on the ethics of firing by way of affecting the appropriateness of blame.

\section{How Do Mass Social Media Outrage Contexts Affect the Ethics of Firing?}

The fact that a firing would occur in a mass social media outrage context is relevant for two critical reasons: (1) it alters the nature of the act from being a mere employment decision to also being an act of blame ("The Firing Claim") and (2) it contributes to the firing qua blame being inappropriate ("The Dependence Principle"). The claims discussed in this section constitute the crux of the argument.

\section{The Firing Claim}

Many acts of firing are not acts of blame. Firing an employee because one can no longer afford to pay his/her salary or because he or she has become redundant, and so on, are not acts of blame. But in some circumstances, firing is an act of blame. Specifically, in my view, when a business fires an employee in response to his/her conduct that gives rise to mass social media outrage, this constitutes an act of blame. ${ }^{11}$

\footnotetext{
11 Those who espouse a reactive attitudes account of blame might find it perplexing to say that the business is blaming. The argument might be: Businesses do not have emotions, so how could they respond through reactive attitudes that constitute blame? I will not enter into the debate concerning group agency (Arnold 2006; Donaldson 1980; French 1979; Hasnas 2012; Hess 2014; List and Pettit 2011; McMahon 1995; Pettit 2007; Sepinwall 2016; Velasquez 1983, 2003; Werhane and Freeman 2003). For now, when I use the term "business," insofar as one is opposed to the idea of group agency, it
}

The act of firing is always the act of terminating employment, but sometimes it also is an act of blame.

Supporting the contention that firing in response to mass social media outrage constitutes an act of blame is the purpose of this section. To be clear, I will not offer a positive argument for this claim, but will instead defend it against one significant worry and motivate the plausibility of the claim. Lastly, my aim in this section is merely to defend the claim that it is an act of blame; the argument for why mass outrage contexts contributes to it being an inappropriate act of blame will follow.

Let's briefly discuss the concept of blame. I am concerned with the ethics of blame expressed through an act that is under our voluntary control; typically, this involves overt blame (McKenna 2013). ${ }^{12}$ As for what precisely constitutes blame, there are many conceptions discussed in the literature. Unfortunately, as Michael McKenna aptly states, "Despite the pervasiveness of the phenomenon in ordinary life, blame is an elusive notion. It is maddeningly hard to nail down a theory that gets the extension even close to right. This is shown by the diversity of strikingly different views about its nature" (2013, p. 119). The difficulties associated with theorizing about blame have even brought some philosophers to abandon the project of providing a conceptual analysis of blame (Fricker 2016).

With that said, I am sympathetic to the thought that "Blame would not be blame...absent the core emotions of anger, indignation, and resentment..." (McGeer 2013, p. 167). So, my sympathies lie in an understanding of blame that resembles a broadly Strawsonian reactive attitudes account in which blame is understood to involve a negative emotional response to another's wrongdoing (Strawson 1962). Two important features of such an understanding of blame are the following: (1) it involves the negative reactive attitudes (e.g., resentment or indignation) that typically bring about in the recipient some form of unpleasantness ("the normative force of blame - the sting it putatively ought to have when directed at one who is blameworthy" (McKenna 2013, p. 121)), and (2) there is a directedness to these attitudes (“...blame includes an attitudinal aspect, where the

\footnotetext{
Footnote 11 (continued)

should be understood merely as a placeholder for the human agent who authorizes the decision to fire.

${ }^{12}$ I am not concerned with when one blames another "in her head," as it were. I grant that in response to wrongdoing, many of us will experience (perhaps involuntarily) blame in the form of anger or other negative emotions; as Allan Gibbard (1992, p. 298) states, "Anger, it seems, will be with us whatever we decide." This citation is due to Baier's (1993, p. 438). This sort of involuntary blame is not my primary focus; my concern is with when we overtly express blame. This is not to say that one voluntarily or overtly intended for blame to be expressed, but rather that one voluntarily or overtly intended to commit the act that expressed blame.
} 
attitudes in question have a distinctive content and focus" (Wallace 1994, p. 75)).

Some readers might worry that because blame within the reactive attitudes framework involves certain emotions, if the person doing the firing is not experiencing these emotions, we might not properly call it "blame." However, it is a mistake to think that expressing emotions requires experiencing the emotion. A novelist can express emotion through his/her words, without having to experience the emotion (Anderson and Pildes 2000, p. 1508). So, the agent/medium channeling the expression of the emotion need not have the phenomenological experience associated with the emotion.

In any case, it seems plausible that we can have a productive discussion of the ethics of blame, even if we do not have a fully worked-out account of the concept of blame. ${ }^{13}$ Importantly, I am claiming that when a business fires an employee who is subjected to mass social media outrage, it is an expression of indignation directed at the employee in a way that counts as an act of blame.

Some might think that this claim is mistaken, that the business is not really trying to blame the employee; it is merely seeking to disassociate. For example, in the Vancouver Riots case, the president of the company stated, "I just didn't feel like what was said was appropriate, and I didn't want any affiliation towards my company with the things he said on Facebook" ("Man fired for applauding Vancouver riot on Facebook" 2011). While the president here does deem the employee's remarks inappropriate, the intention to disassociate is also plain. It seems plausible that in many cases the intention to disassociate plays a prominent role in the reasoning of employers who fire an employee who is at the center of mass social media outrage.

I note two points in response. First, one important feature of blame is that it is not wholly determined by a person's intentions. Acts in certain social contexts are acts of blame, regardless of one's intentions (Anderson and Pildes 2000). ${ }^{14}$ For example, when a judge hands down a prison sentence, it $i$ a form of condemnation that expresses blame, regardless of whether the judge's intentions were entirely unrelated to blame (e.g., if the judge's intention in sentencing the defendant was to help the ailing defendant in abject poverty secure access to the health care provided in prisons). Similarly, when a business fires an employee immediately after

\footnotetext{
13 The most prominent contemporary accounts of the concept of blame are Wallace's $(1994,2011)$ [an account inspired by the work of Strawson's (1962)], Scanlon's (2008), and Sher's (2006). For a recent compilation on the philosophy and ethics of blame, see Coates and Tognazzini's (2013).

14 For a recent discussion of some of the expressive dimensions of business ethics, see Matthew Caulfield's (Forthcoming). For an important critique of semiotic objections to the commodification of certain goods and services, see Brennan and Jaworski's (2015).
}

conduct that has generated mass outrage, the act of firing is a form of blame, regardless of whether the business intended only to disassociate.

In the kinds of cases we are considering, thousands condemn the employee and many call upon the employer to terminate the employee. Here are a few of the tweets involving the woman in the AIDS-tweet case:

- "[the employer] needs to fire this racist, stupid bitch!"

- "We are about to watch [her] get fired. In REAL time. Before she even KNOWS she's getting fired."

- "I cannot stop laughing at the sheer stupidity of [her], enjoy your time in the unemployment line..."

- "No words for that horribly disgusting, racist as fuck tweet from [her]. I am beyond horrified"

Thousands of such tweets create a context in which the act of firing is no longer merely employment termination, it also is an act of blame. ${ }^{15}$

Second, businesses in mass outrage contexts often couple the firings with condemnatory press releases. For instance, in the AIDS-tweet case, the employer publicly announced: "We take this issue very seriously, and we have parted ways with the employee in question. There is no excuse for the hateful statements that have been made and we condemn them unequivocally." ${ }^{16}$ Her firing was not only an expression of blame, it was also explicitly communicated as such. If a business wants to claim it has fired an employee for nonmoral reasons related to disassociating, coupling the firing with a condemnatory press release would be dishonest and disingenuous.

When a business fires an employee in mass social media outrage contexts, especially if a business pairs the firing with a condemnatory press release, it is engaging in blame. But this alone does not license the conclusion I am arguing for: that mass outrage contexts can contribute to the firing being an inappropriate act of blame. Indeed, there are many

\footnotetext{
15 The social media responses involved in several of the mass outrage cases sometimes seems to take the form of what Tosi and Warmke (2016) call moral grandstanding. This involves, roughly, engaging in public moral discourse to solicit positive judgments about one's own respectability.

${ }^{16}$ Despite this explicit condemnation, [the employer] in the next sentence states, "We hope, however, that time and action, and the forgiving spirit, will not result in the wholesale condemnation of an individual who we have otherwise known to be a decent person at core" (Coine and Babbitt 2014, p. 16). This is an interesting inclusion and one that seems to be in tension with condemning "unequivocally." The question of how this qualification interacts with the condemnation, and to what extent it can meaningfully be uttered in the same breath as the expression of condemnation, may turn on difficult issues in the philosophy of language related to the relationship between semantic and pragmatic content and meaning (Grice 1989).
} 
instances of blame that most think are well justified and appropriate in response to wrongdoing. As such, the next section concerns why the business blaming through firing in mass social media outrage contexts is of particular ethical significance.

\section{The Dependence Principle}

While it is widely accepted in the philosophical literature that blame is a fitting response to wrongdoing ${ }^{17}$, some scholars have recently articulated certain conditions that one must satisfy in order to appropriately blame another (Fricker 2016; Friedman 2013; Radzik 2011; Watson 2013). Since blaming is an action, moreover an action with corrosive effects, one can perform it more or less appropriately, and in better or worse ways. Marilyn Friedman notes:

[I]n addition to asking what conditions a person should meet to be a legitimate recipient of blame, we should also ask what conditions a person should meet to engage responsibly in the act of morally blaming others... If the recipient of blame must meet certain criteria to be blameworthy, does not the blamer have to meet certain criteria to be blamer-worthy? (2013, p. 272).

The point is that blame can have certain unseemly and harsh dimensions, so one ought to wield it with care. The ethics of blame emerges as a significant area of inquiry once one recognizes that a person being morally responsible or blameworthy does not settle the question of whether one ought to blame that person-there are certain conditions one must meet. ${ }^{18}$

The ethics of blame is still a nascent area of inquiry with many unsettled questions, including, for example, why, if at all, hypocritical blaming is inappropriate (Cohen 2006; Fritz and

\footnotetext{
17 As Maura Priest notes, "It is...uncontroversial, in the usual circumstances, that wronged parties can aptly blame their wrongdoer" (2016, p. 619). Others think that blaming is something that we have a right to do: "That there is a right to blame is an assumption that [R. Jay] Wallace, [Macalaster] Bell, and others in the literature...seem to share" (Fritz and Miller 2018). The few who do not hold this view are defenders of skeptical accounts of responsibility that suggest that blaming does not make sense because agents are never truly blameworthy or morally responsible (Pereboom 2006, 2014; Rosen 2002, 2004). I am not defending the view that agents are never blameworthy. Indeed, a critical aspect of my argument is that agents are blameworthy, and yet it can be inappropriate to blame them.

18 Douglas Husak (1992) notes a similar point in the context of stateimposed punishment. He suggests that even retributivists must evaluate certain consequentialist considerations-for example, the suffering that fulfilling a desert claim might impose on "dependents or third parties" (Husak 1992, p. 449). The point is simply that the fact that a person deserves punishment does not conclusively establish that we ought to punish that person.
}

Miller 2018; Todd 2017; Wallace 2010), how "moral standing" is a sensible notion if morality is universal (Smilansky 2006), and so on. Despite the lively ongoing debate, one aspect of the debate remains uncontroversial: it is wrong to blame a person who does not deserve blame or blame a person beyond what he or she deserves. Consider the following example:

Cubicle: When Gyu-min arrives at work, he realizes his Montblanc pen is missing. He frantically searches his office and becomes convinced that the custodian stole it. Contrary to what Gyu-min thinks, the pen is in the conference room-he had used it to take notes during a client meeting and had left it on an adjacent seat.

If Gyu-min were to blame the custodian, he would wrong the custodian. This would be so even if the custodian would not in any way be materially harmed. An apology would be in order. If one blames someone who does not deserve blame or blames someone beyond what he or she deserves, the blame recipient is wronged. This fact has implications for our investigation.

Returning to the employment context, let us consider two possibilities. First, suppose the employee's conduct is not unethical, and he/she does not deserve blame. In such cases, if the business blames the employee through firing, then the business acts wrongly (and so, too, do those blaming the employee on social media), because it is wrong to blame someone who does not deserve blame. For example, a college student appeared to have posted racial slurs to her Facebook aimed at the participants of the 2014 Ferguson protests. The AMC theater at which this college student worked began receiving phone calls with demands that she be terminated (Scheff and Schorr 2017, pp. 72-73). As it turns out, the student's ex-boyfriend had hacked into her Facebook page and it was he who had posted the slurs. In this case, if AMC had blamed her through firing, the fact that one should not blame someone who does not deserve blame, would have contributed to it being an inappropriate act of blame.

The second possibility is more interesting: Suppose the employee's off-duty conduct is wrong and he/she does deserve blame-perhaps the employee even admits to the wrongdoing. At first blush, it might seem that the employee can clearly be blamed without the blame being inappropriate. Nevertheless, the fact that a person deserves blame does not settle whether one ought to blame him/her. Here is the critical point:

The Dependence Principle The appropriateness of an act of blame depends in part on how much others blame. $^{19}$

\footnotetext{
19 The nature of the relation in the dependence principle must be clarified. This is because there is no directionality built into the principle, and the principle may seem consistent with saying that
} 
Respecting this principle is important because one's act of blaming might subject the recipient to blame beyond what he/she deserves. So, one must consider how much blame others have subjected the employee to as well.

Suppose that, while seated on a commuter train, Camila angrily berates an adjacent passenger in a way that is clearly wrong. We might think that the other passengers in the vicinity ought to blame Camila. Still, if these neighboring passengers have blamed her, there is the further question of to what extent it would be appropriate for the other passengers to blame: should passengers in adjacent train cars now cross over into the car with Camila and proceed to blame her? When she exits onto the platform, should commuters waiting, the turnstile attendant, and custodial staff blame her as well? Once she leaves the station, she passes the honey-roasted peanut vendor, the halal food truck vendor, and several cab drivers waiting for passengers: Should they all blame her too? Answering these questions affirmatively is implausible. ${ }^{20}$

Similarly, even when the employee has acted wronglysuppose even that there is strong evidence of this wrongdoing and the employee is extended due process, or perhaps the employee even admits to the wrongdoing - it does not settle whether the employer ought to blame the employee through firing. This is because, in mass social media outrage contexts, given that the employee has already been blamed by thousands, an employer's added blame is likely to subject the employee to blame beyond what he/she deserves. If one fails to acknowledge the significance of the dependence principle,

\section{Footnote 19 (continued)}

the more that others are blaming, the more your blame is appropriate- a claim I do not endorse. We might then amend the principle to say that the appropriateness of your act of blame depends inversely on how much others are blaming. But this still does not capture what is at stake. If you are the second person to blame someone for some serious wrongdoing, it does not mean that your act of blame is less appropriate than the act of blame performed by the first person to blame. So, more precisely, the appropriateness of an act of blame depends (in part) on whether the contributions of others to the amount of blame $\mathrm{P}$ deserves would render your added act of blame to be one that contributes to blame beyond $\mathrm{P}$.

20 An observation that an anonymous reviewer helpfully raises pertains to the much maligned lex talionis penal principle, famously associated with the phrase "an eye for an eye, a tooth for a tooth." This principle, at least in its literal forms, is no longer taken seriously due to its having unduly harsh implications and the impracticality of applying it. But importantly, even with principles holding as severe of implications as lex talionis, there is still an upper limit to the punishment meted out. The phrase is thus not "two eyes for an eye." There are, of course, important differences in the justifications for stateimposed punishments and informal social sanctions associated with expressed blame for wrongdoing, but the reasons we set upper limits for the punishments for many crimes, even serious ones, seems at the least worth keeping in mind. this would suggest that one wrongdoing, however major or minor, justifies subjecting a person to blame from a limitless number of people for an indefinite amount of time. This would be an implausible result. It would erode our ability to treat certain acts of wrongdoing as deserving more blame than others. Critically, it would plausibly render violence to the fundamental principle that it is wrong to subject a person to undeserved blame.

At this point, one might raise what we might call "the epistemic demandingness objection," the worry that the view I have advanced is too epistemically demanding for prospective blamers. That is, if deciding whether to blame requires comparing how much blame happens with how much blame is deserved, this imposes too onerous of an investigatory burden on prospective blamers and may require the prospective blamer to make potentially unjustified empirical assumptions. ${ }^{21}$

There are a few points to note in response. First, the importance of considering how our actions interact with the behavior of others is not an unfamiliar one in ethics: the general point I make resembles one that Derek Parfit makes in his influential discussion of the moral importance of considering the joint effects of our actions:

It is not enough to ask, 'Will my act harm other people?' Even if the answer is No, my act may still be wrong, because of its effects. The effects that it would have when it is considered on its own may not be its only relevant effects. I should ask, 'Will my act be one of a set of acts that will together harm other people?' The answer may be Yes" (1984, p. 86).

Similarly, when deciding whether to blame, it is not enough to ask, "Does the person deserve blame?" Even if the answer is "Yes," my blaming that person may still be wrong when considered in view of whether and how much others

\footnotetext{
${ }^{21}$ I owe this objection to an anonymous reviewer. This reviewer also raises the concern that my account may have chilling effects on prospective blamers who would be justified in blaming. The thought is that my account might result in those who would be doing nothing wrong by blaming to opt out of blaming. This possibility seems to me a bullet worth biting primarily for the following reason: few theorists argue that one acts impermissibly by failing to express blame to a wrongdoer. We are not obligated to express blame, and this is so even in response to many heinous wrongdoings. Expressing blame is typically regarded as optional. If I decide to brush off the wrong, think it not worth the emotional commitment to blame, or decide not to blame for other reasons, including that the wrongdoer has been blamed enough, this is entirely my prerogative-I have done nothing wrong by failing to blame. On the other hand, blaming someone who does not deserve blame or blaming someone beyond what the person deserves is unjust and wrong. So, even if there are some cases in which a person who could justifiably blame decides not to, given that this person was under no obligation to express blame, this seems to be a reasonable cost associated with avoiding doing something that is unjust and wrong.
} 
are blaming. In deciding to blame, it is not enough to ask whether the person deserves blame; one must also consider whether and to what extent others are blaming. ${ }^{22}$

Still, the epistemic demandingness objection does seem to have force, especially from the perspective of someone who is considering blaming: "How could I possibly know how many people are going to also blame this person, how strongly, and for how long?" Insofar as I am making claims about an agent's character, moral responsibility, or blameworthiness, for subjecting another to undeserved blame, the thrust of this objection is troubling and may seem to undermine the plausibility of my position.

This is not, however, what I am claiming. I am instead concerned with whether the fact that the blaming through firing occurs in a mass outrage context figures into the deontic status, or permissibility, of the act itself. I am not making a judgment about the character, blameworthiness, or responsibility of the agent performing the act. While the epistemic worries raised by this objection may affect claims about a manager's moral responsibility or character for the firing, it has less of an effect on the moral status of the act itself; that is, whether the act of blaming through firing in a mass social media outrage context contributes to the act being wrong in the first place.

Moreover, even with respect to judgments pertaining to an agent's moral responsibility or character, the epistemic demandingness objection has greater force in the context of ordinary interpersonal blaming than it does in the context of the business blaming through firing in mass social media outrage contexts. This is because when an employee is at the center of mass social media outrage, the business is already aware that the employee has been harshly blamed by thousands of people. ${ }^{23}$ Knowing this fact should provide

\footnotetext{
22 One might object to my appealing to Parfit in this way because the context of his discussion pertains to harms brought about by the joint effects of our acts, whereas the focus of our discussion is on wrongful blame. While this is of course correct, the critical underlying insight still stands-the morality of an act is affected by what others do.

Moreover, there is reason to think that there are also significant harms associated with blaming. Recent empirical studies lend support to how a blame recipient, in virtue of the alienation and rejection that is fundamentally tied up with blaming practices, can be affected as he or she would be if physically harmed. That is, certain social pains are phenomenologically and physiologically akin to physical pains-for example, those associated with assaults and injuries. Psychologists Naomi Eisenberger and Matthew Lieberman state, "We have recently proposed that physical pain-the pain experienced upon bodily injury - and social pain - the pain experienced upon social injury... share neural and computational mechanisms" (2004, p. 294). Others have shown that medication such as Tylenol, typically prescribed for physical pains, can reduce the severity of socially induced pains (DeWall et al. 2010).

${ }^{23}$ For a brief mention of the effects of social media on proportionality considerations, see footnote number nineteen in Radzik's (2016, p. 200). For a discussion of the effects of multiple blamers on proportionality, see Radzik's (2014, p. 658). For important recent empirical work on how expressions of disapproval directed toward a wrong-
}

strong reason for the business to come to see that its added blame will be undeserved and thus can contribute to the firing being an inappropriate act of blame. ${ }^{24}$

It is now worth flagging two limitations to the scope of my argument. First, for my argument to generate a reason against firing, the act of firing must be an act of blame. This is why the fact that the firing happens in mass outrage contexts is especially significant ("The Firing Claim"). ${ }^{25}$ So, the argument is not an argument against firing as such, but rather against blaming inappropriately, which can be done through firing. Second, I am not suggesting that the mass social media outrage cases that we are examining are ones where nobody should have blamed the wrongdoer. Nor am I claiming that any chance of undeserved blame is unacceptable; this would render nearly all acts of blaming too risky to take on and may result in an implausible account. But considering the extent to which a person has already been blamed, does seem to be a reasonable exercise of moral caution. ${ }^{26}$

\section{Footnote 23 (continued)}

doer when done in isolation may be perceived in a positive light, but how the same expression of disapproval in mass social media outrage contexts can come to be seen as bullying see Sawaoka and Monin's (2018).

${ }^{24}$ Even readers-I have in mind those who espouse some version of Scanlon's (2008) conception of blame that understands blame in terms of altering relations-who may find it implausible that blame is aggregative have grounds to endorse my conclusion. What is important is that additional acts of blaming alter the context, meaning, and significance of blame. And the meaning and significance of your act of blaming changes in response to what other people are doing.

25 If an employee acted immorally off-duty and only the business was to learn of this conduct and were to covertly fire the employee in a way that does not generate press and does not qualify as blame, my argument may not tell against this (though there may still be good reasons related to moral standing or free speech (Barry 2007a) for the business not to fire the employee). If the business, say, waited out the storm of outrage and then fired the employee discreetly, or somehow canceled the implicature (Grice 1989) that the employee is being blamed through the firing, then this too would be something that my argument might allow for. (It is worth noting that I am discussing only a limit on my thesis; I am not making a positive assertion in support of firing in these cases. That would be a bold claim that would require at least as much justification as the thesis I defend).

${ }^{26}$ But what about a situation where the marginal blame that the business adds through firing contributes only an amount of blame up to and at most equal to what the employee deserves for his or her wrongdoing? In such a case, one might point out, the business's blaming through firing would not subject the employee to undeserved blame. While firing in this case may not be problematic on the grounds of subjecting another to undeserved blame, firing the employee may nevertheless be morally reckless. This is because the business cannot control how much additional blame will fall upon the employee after the firing. In other words, the firing may not be the final act of blame that hits the mark for how much blame is deserved. The firing in the sorts of cases that I am considering is likely to generate further publicity and may invite more blame, and in this sense, the business's blame might very well be part of a collection of blam- 
To conclude, there must be a limit to how much blame a person can justifiably be subjected to in response to the sorts of conduct we have been considering. However, social media allows thousands of individuals to participate in the blaming of any other individual, with few limits in terms of intensity or duration. If a person's perpetration of some wrongdoing provides sufficient justification for a limitless number of parties to express blame, this would undermine a fundamental aspect of desert in blame, namely, that one should not subject a person to undeserved blame. The dependence principle thus urges the manager to recognize that the extent to which others have already blamed a wrongdoer can affect the appropriateness of his or her decision to blame the employee through firing. The fact that a firing would occur in a mass social media outrage context generates an important ethical reason weighing against the act: it contributes to the firing constituting an inappropriate act of blame.

\section{What are Some of the Other Factors to Consider When Blaming and Firing?}

Where does this leave us? Unfortunately, there is much more work to be done on the topic of the ethics of blame in the context of organizational actions. While the argument I have developed offers one important ethical consideration against blaming through firing, the ethics of blame is a complex matter and is sensitive to a number of factors beyond those raised by my argument. Furthermore, blame-related considerations are not the only ethical considerations that figure into the ethics of firing more generally, nor are ethical considerations the only considerations that enter the manager's all-things-considered judgment to fire. Let us now briefly touch on some of these added layers of complexity.

In thinking about some of the other considerations that bear on the appropriateness of blame, a recent framework developed in work by Marilyn Friedman (2013) is helpful. On Friedman's account, for an agent to blame another responsibly, the act of blaming must meet at least the following three conditions: "warrant, commitment, and responsiveness" (2013, p. 272). The warrant condition concerns one's justification in thinking that "the wrongdoing really occurred, the blame recipient did it, and the blame recipient was a morally competent agent" (Friedman 2013, p. 274). The commitment condition requires one "to comply with the specific moral norms to which one holds others" (Friedman 2013 , p. 274). The responsiveness condition requires that the

Footnote 26 (continued)

ing acts that together exceed the amount of blame the employee deserves. blamer has an "openness to dialogue with the blame recipient about the blame charges and flexibility in being able to adjust one's blame if appropriate as a result of that dialogue" (Friedman 2013, p. 274). According to Friedman, these three conditions are a non-exhaustive set of necessary conditions for responsibly blaming an individual.

How might Friedman's framework be considered in the business context? First, the warrant condition might suggest that the extent to which a manager's understanding of the employee's misconduct is grounded in reliable epistemic sources and is corroborated by high-quality evidence, positively affects the extent to which the manager is blaming responsibly. If the decision to express blame through firing is grounded merely on hearsay or viral internet rumors, without accounting for the employee's testimony and other forms of evidence, this would make the business a less responsible blamer.

Second, the commitment condition might suggest that to the extent that a business is blaming an employee for a wrongdoing it ordered, was complicit in, or performed in the past, it would to that extent make the business a less responsible blamer. In other words, the commitment condition cautions against hypocritical blaming, broadly construed. For example, if the employee made some racially insensitive remark on social media that generated mass outrage, but the business itself had recently run a racially insensitive advertisement campaign, this may make the business's blaming of the employee less responsible. Even if the business had not itself perpetrated a similar wrongdoing, if a business had policies or a culture that helped sustain or promote an environment in which actions similar to the employee's wrongdoing were welcomed or authorized, then the business's blaming of the individual for acting in a way that its policies and culture promoted would be less responsible because the commitment condition would be undermined. Of course, insofar as the business has rectified or sincerely acknowledged its own past wrongdoings of the sort that it is blaming its employee for, this would signal a renewed commitment to the values the business holds the employee accountable for, and to that extent, it would not violate the commitment condition (Friedman 2013, p. 282).

Third, the responsiveness condition is undermined if a business blames an employee through firing without giving the employee an opportunity to explain, excuse, or justify his or her alleged misconduct. Unfortunately, firms may face special difficulties in satisfying the responsiveness condition. This is because upon being blamed through firing, the employee may lack a clear target to whom he or she can direct his or her response or challenge (either with respect to the content of the criticism or the standing of the business to deliver the criticism). It also makes it much more difficult for the firm "to revise the original blaming accusation if it is called for by what emerges in the dialogue" (Friedman 
2013, p. 276) - after all, the business has already fired the employee. This is a less significant problem in interpersonal blaming. For instance, when a person blames me, it is fairly obvious who I should address: the person blaming me. I can reject the person's standing to blame, understanding of the situation, the merits of the normative claim undergirding the criticism, and so on. The person might then revoke his or her blaming accusation. But when a business blames by firing an employee immediately after learning that the employee is at the center of mass social media outrage, the recipient of the blame does not have a meaningful opportunity to defend himself or herself against the criticism. This puts the employee in a position where it may be entirely unclear who to engage with in a dialogue regarding the blame charge and leaves the employee without an opportunity to respond to the blame.

One practical way to remedy the difficulty of satisfying the responsiveness condition in the business context is secured by extending the employee due process prior to blaming through firing. Providing the employee a hearing prior to arriving at the judgment to terminate the individual offers the employee an opportunity to explain, excuse, or justify his or her conduct and engage in the very sort of moral dialogue that the responsiveness condition demands. Additionally, extending due process to the employee can also help better satisfy the warrant condition by helping the business obtain better epistemic justification; the business might consider more diverse sources of evidence (including the employee's testimony) and thus not merely have to rely on potentially epistemically corrupt sources of evidence from distant social media participants. Examining the requirements associated with the ethics of blame then has brought us a surprising theoretical benefit: a novel and independent justification for the moral importance of providing the sort of due process in the workplace that business ethicists have long been arguing for (Werhane and Radin 1999), at least in mass social media outrage contexts. This is because extending due process to employees can simultaneously help satisfy the warrant and responsiveness conditions associated with the ethics of blame and help managers blame more responsibly. ${ }^{27}$

\footnotetext{
27 To be sure, there is much more to be said about the ethics of blame in organizational contexts. For example, thus far, we have considered cases where the business is not the direct victim of the employee's off-duty conduct (even though, of course, the business may have been indirectly harmed in these cases). We might plausibly think victims of wrongdoing maintain special standing (Cohen 2006; Todd 2017) to express blame regardless of the extent to which others have blamed the wrongdoer. Importantly, this special status of victims would be just as true if the business were the victim of the employee's wrongdoing. For example, when an employee of a fast-food chain posted an extended Facebook live video from the kitchen of the restaurant that generated mass outrage (in this video, one of the employees threatens to spit on the food, claims to wipe his nose with the food and to have cleaned the floors with burger buns, talks about having sex with customers in the kitchen, is seen lighting a cigarette in the
}

But it is important to keep in mind that whether a given act of firing is an inappropriate act of blame is not the only ethical consideration that figures into whether the firing is all-things-considered permissible. For example, the safety and well-being of other employees within the firm are important ethical factors (but not blame-related ones) for managers to consider. Such factors can together, in some circumstances, point in favor of firing, even if the firing may be an inappropriate act of blame. On the other hand, free speech related considerations (Barry 2007a, b) are also ethical concerns (but not blame-related ones) that may point against firing, even if it is judged that blame is appropriate. Remaining factors that bear on the ethics of firing include the length of the relationship with the employee, the nature of the position the employee occupies, whether or not the employee is a repeat offender ${ }^{28}$, the perspective of the victim (when there is an identifiable victim) of the employee's wrongdoing, whether the misconduct came to light through a breach of privacy ${ }^{29}$, whether the employee apologizes, and so on.

A more complete theory of the ethics of firing would also need to account for how and why, if at all, the fact that misconduct occurs on-duty instead of off-duty matters. For example, most would agree that an employer requires less justification to fire an employee for on-duty conduct, than with off-duty conduct. One might plausibly think that insofar as the employee's conduct occurs on-duty this generates sufficiently weighty justification to fire. Given this, consider the engineer who was fired by Google in response to circulating a memo ("Google's Ideological Echo Chamber")

\section{Footnote 27 (continued)}

kitchen, and is heard saying "fuck corporate." The man who posted the video later claimed it was merely a publicity stunt to further his career as a comedian and rapper, and denied having done the things he talks about having done in the video), the restaurant plausibly maintained standing to blame these employees through firing, even though others had already subjected the participants in the video to blame (Scheff and Schorr 2017, p. 106). (Of course this point cuts both ways, insofar as a business lacks standing to blame employees for certain kinds of off-duty conduct this is a different sort of consideration that would count against the appropriateness of blame.) The point is that considerations pertaining to subjecting a wrongdoer to undeserved blame is only one category of considerations, albeit an important category, that figures into whether blame would be appropriate. Friedman's (2013) framework helps account for some of the other considerations that can help a business blame more responsibly. Nevertheless, the ethics of blame is a thorny matter with many remaining issues.

28 There are interesting issues with respect to how we ought to treat repeat offenders, and whether we can justify treating them more harshly than first-time offenders. My attention was first drawn to this issue in footnote number seven in Husak's (1990).

${ }^{29}$ Specifically, it could be of moral significance if the person volunteered the content that constituted the wrongdoing in a public forum (or on social media) rather than being covertly taped or eavesdropped on 
among his colleagues that called into question the identity based diversity (and related) corporate initiatives at Google (Wakabayashi 2017). This memo was voluntarily circulated in a workplace mailing list and directed at other colleagues. The memo generated strong reactions; some supported both the content of the memo and the right of the engineer to voice his concerns, and others harshly criticized the memo, arguing that the memo advanced harmful gender stereotypes. We might think that if the engineer had circulated his memo among his friends on his personal email address, this is less plausibly on-duty, insofar as his friends were not also Google employees. But this was not so. The memo was circulated on a Google mailing list and to other Google employees. In this case, whatever one thinks of the veracity and plausibility of the content of the memo, the conduct was squarely on-duty.

Of course, the distinction between on-duty and off-duty conduct is more fraught than a binary taxonomy suggests. Several factors complicate this distinction, not the least of which is technology. ${ }^{30}$ Also, the diversity of roles, jobs, and organization types and purposes seem to contribute to the unique and elusive boundaries for what counts as off-duty conduct. ${ }^{31} \mathrm{I}$ of course will not be able to settle the boundaries

\footnotetext{
${ }^{30}$ We of course can no longer treat not being on the physical premises of the workplace as a sufficient condition for being off-duty. Moreover, our employer affiliations are often linked to our social media accounts, colleagues are on our social media "friend lists," and finally, we can receive and respond to work emails and messages through other workplace communication platforms (e.g., Slack) at nearly all times and in all places.

${ }^{31}$ Consider how, with celebrities, the basis for endorsement deals is often not what the celebrity is doing for the business, but rather it is the association itself; the person is not plausibly separable from his/her work-related capacities. For example, when the Carolina Panthers quarterback Cam Newton expressed amusement at the fact that a female reporter was asking him questions pertaining to football routes, the yogurt company Dannon announced that they would no longer work with Newton and would remove him from advertisements. Something similar may be said of c-suite executives (Barry 2007b, p. 286): the executive is not neatly separable from his/her work and so may almost always qualify as "on-duty." For example, in the summer of 2012 when many were angered by Chick-FilA's stance against same-sex marriage, the CFO of a medical device manufacturer posted a video of him chastising an employee working at a Chick-Fil-A drive-through in which he says, "Chick-Fil-A is a hateful corporation, I don't know how you live with yourself and work here. I don't understand it. This is a horrible corporation with horrible values. You deserve better" (Diaz and Effron 2015; Scheff and Schorr 2017, p. 20). He was met with mass outrage for confronting this drive-through-worker and then terminated from his position as CFO. In another example, perhaps employees of firms that create environmentally friendly beauty products are justifiably held to a higher moral standard with respect to the environment; for example, if an employee of such a firm is seen dumping his/her garbage into the ocean, we might think that this properly counts as on-duty conduct, even if the employee was away on vacation.
}

of this distinction within this article. ${ }^{32}$ But I mention this as another factor that complicates the ethics of firing. ${ }^{33}$

Once we expand beyond the ethics of firing and consider the many non-ethical factors that a manager must attend to, the decision to fire becomes even more delicate. Identifying the complete set of factors that should figure into the allthings-considered decision to fire would require developing a comprehensive theory of firing, a task that I will not be able to pursue here. That being said, in the remainder of this section, I would like to consider three factors that some may regard as pointing strongly in favor of firing in mass outrage contexts: (1) the concern that an employee being at the center of mass social media outrage generates a strong economic reason to fire the employee ("The Economic Burden Consideration"), (2) the worry that humans are habitual and that firms are morally justified in firing the employee for

\footnotetext{
32 Given these complications, some might reasonably wonder why we do not simply abandon this distinction and treat it as a remnant of an archaic understanding of employment. While the boundaries between on-duty and off-duty conduct seem to be elusive, perhaps even continuously moving, it seems still a significant cost to do away with entirely. That the line is hard to draw precisely does not entail that there is not a line. Moreover, there are important reasons pertaining to the democratic process and the protection of speech that Barry (2007a, b) develops for why we should not abandon the distinction. Even putting these sort of macro-level, political philosophy considerations aside, intuitively, it does seem that we do still take the distinction seriously and continue to see certain acts as properly falling outside the purview of managerial decision-making. For example, it seems wrong for a manager at a tech company who believes vaccines are harmful to terminate an employee who vaccinates her child. It does not seem to be any of the manager's business. In order to be able to preserve this level of separation, we should continue to regard the on-duty and off-duty distinction seriously, even if it requires significant revision.

33 Theorizing about what constitutes on-duty versus off-duty conduct is in some senses more difficult than recognizing cases of on-duty conduct: a McDonald's employee raising her middle finger and berating a Hispanic customer, demanding that she say "Donald Trump" and asking her, "Can you spell 'deportation'?"(Dyches 2017) clearly counts as on-duty. This is why it is more straightforward to offer some indicators of when conduct is on-duty, even if we are unable to offer a comprehensive account of these indicators. Some strong indicators include whether the conduct (a) was performed on (or using) workplace property (physical or digital), (b) directly involved other co-workers, colleagues, or customers, or (c) involved the employer's logos and emblems. These are not sufficient conditions, but rather strong indicators, or paradigmatic features, of being on-duty. That said, the greater the number of these indicators that are satisfied, the more plausible it is that the indicators become jointly sufficient for the conduct to be properly regarded as on-duty.

How might this discussion affect our current investigation? One reasonable thought is this: insofar as we consider the on-duty/off-duty distinction as a spectral notion, the strength of the ethical reason my argument generates against blaming through firing could be understood as being positively related to the extent to which the conduct is off-duty. Or alternatively, the greater the extent to which certain conduct is on-duty, the more plausibly does this fact outweigh the ethical considerations pertaining to the appropriateness of blame.
} 
this reason ("The Habitual Wrongdoer Consideration") and (3) the claim that firms simply should not tolerate the sort of conduct that generated mass outrage in the kinds of cases we have considered ("The Business Should Not Tolerate The Conduct Consideration"). I offer some reason to think that these considerations may not weigh quite as heavily in favor of firing as one might initially think.

\section{The Economic Burden Consideration}

Some might reasonably worry that an employee's being the focus of mass social media outrage imposes significant economic burdens, and will always, or almost always, constitute good financial reason to fire. While whether this is so will of course ultimately turn on further empirical investigation, there is some reason to think that this worry is at least not obviously correct.

Given the notoriously short attention spans of outraged social media participants (Ronson 2015a), it is difficult to conclude that retaining the employee will be too economically burdensome. Moreover, it is not clear that the outraged social media participants are motivated or influential enough to harm the business, especially when the business has a customer base that does not overlap with those outraged. Also, there can be significant costs involved in finding a replacement candidate and training the newly hired employee (Allen et al. 2010; Dube et al. 2010). Until a suitable candidate is hired and trained, others in the workplace may need to pick up the slack, as it were, and this might adversely affect their productivity (Bauer et al. 2007). These are non-trivial costs that may ultimately outweigh the costs of continuing to employ the subject of the mass social media outrage. By hypothesis, the employer knows the subject of the mass outrage to be a productive employee.

To be clear, I am not suggesting that there are never economic disruptions in mass outrage contexts; this is implausible. Rather, I am suggesting that we need not think that the economic case for termination is somehow obvious, or a priori justified. Of course, there may be circumstances in which there is a strong economic case for firing the employee. But, even if the firing in such cases is all-thingsconsidered justified, the manager should be aware that there may still be some ethical costs associated with the decision-for instance, subjecting the employee to undeserved blame.

\section{The Habitual Wrongdoer Consideration}

One might argue that managers are justified in firing in the sorts of cases we are considering due to the fact that humans are habitual and are thus prone to repeat wrongdoings. A manager might think, "I just cannot risk this happening again, and if the person did it once, what's to stop it from happening once more, or worse yet, while at work." One might point out that even in institutions that are typically seen as moral exemplars (or at least ought to be seen as moral exemplars) such as universities and churches, there have been repeated instances of serious wrongdoings, often by the same individuals. ${ }^{34}$ While I am sympathetic to this worry, there are a few things to say in response.

The peculiarity of using a statistical generality about a population (e.g., that humans are habitual), absent evidence, to justify treating someone as though that he/she instantiates that generality (e.g., that this employee is a habitual wrongdoer) is brought ought vividly when considering other moral phenomena. Consider the case of forgiving. We might make the following plausible generality: humans are forgiving. However, after I wrong someone, it would be odd for me to presume that I have been forgiven, merely because of the generality that humans are forgiving. I should neither act as though I have already been forgiven, nor that I will be forgiven, even if it is true that humans forgive another as a statistical matter-I need to in fact be forgiven. Similarly, in considering our response to an employee's alleged wrongdoing we should not assume that he or she is a habitual wrongdoer, without evidence of the person in fact being a habitual wrongdoer.

Perhaps more importantly, presuming a person to be a habitual wrongdoer due to one instance of wrongdoing seems to disrespect that person's agency: it fails to treat the person as an autonomous agent with the capacity or freedom to change. It seems to write off the possibility that the person has "turned a leaf," as it were. These are significant moral costs. Though we might point to statistical generalities when describing the behavior of populations, presupposing that the generality is true of a particular person, absent evidence, disrespects that person: it treats the person as a predetermined statistical pattern, rather than as a person who has the capacity to choose. ${ }^{35}$

\section{The "Business Should Not Tolerate the Conduct" Consideration}

A different consideration that may lead some to believe that the business should fire the employee in mass outrage contexts may go something like this: while the woman's tweet in the AIDS-tweet case may not be as bad as assault or other heinous wrongs, it is still abhorrent and should not be tolerated. Perhaps some may even regard the tweet as blatantly racist. For this reason, the thought may go, the business should blame through firing. ${ }^{36}$

\footnotetext{
${ }^{34}$ I thank an anonymous reviewer for raising this objection.

35 I thank Alan Strudler and Matthew Caulfield for the point made in this paragraph.

${ }^{36}$ I owe this objection to an anonymous reviewer.
} 
Even if we grant that businesses should not tolerate conduct like in the AIDS-tweet case, we still face the question of just what not tolerating something requires. Does not tolerating conduct like in the AIDS-tweet case require the employer to respond with one of the most severe sanctions it has available? I suggest that plausibly not.

As a general matter, not tolerating misconduct does not seem to necessitate responding with a severe sanction, let alone one of the most severe sanctions available. For example, suppose Arjun does not tolerate being disrespected. Perhaps some would understand this to mean that if disrespected, Arjun will punch the person who disrespected him. But not tolerating disrespect certainly does not seem to necessitate (or permit, for that matter) this severe a response. Simply asserting that one will not stand for being disrespected in many instances will suffice. Moreover, the conceptual connection between the extent to which we do not tolerate $\mathrm{X}$ and the severity of our response to $\mathrm{X}$ may not be as tightly linked as we might initially suppose; just because Arjun punches a person in response to disrespect does not mean that Arjun tolerates being disrespected less than someone who responds to disrespect by verbally articulating that he/she will not stand for being disrespected.

Consider also the context of punishments disbursed by the state. It is true, the state should not tolerate shop lifting. But not tolerating shoplifting does not require that the state respond with its most severe available punishment. Of course, state-imposed punishment is different in several important ways from business responses to employee wrongdoing. But what's surprising is that some of the very features that make it an imperfect analogy point in favor of a more tempered response in the business context: With respect to the state disbursing punishment, there are various safeguards, protocols, and so on, that mitigate against the risk of unjustly disbursed punishment. But these safeguards are missing in the context of sanctions disbursed by employers.

To summarize, it does not seem at all clear that not tolerating the employee's misconduct requires termination. In any case, even if one insists that the business ought not to tolerate the sorts of conduct in the kinds of mass social media outrage cases we have been considering, there may be other ways for a business to respond in lieu of firing.

\section{How Might a Business Respond Other Than by Firing?}

In this section, I begin with some reflections directed at those who, even after considering the arguments marshaled in the article thus far, remain hesitant to forgo the thought that businesses should fire employees in the mass outrage contexts we have been considering. I then explore the question of how, if at all, a business might still be able to blame, even if it does not fire the employee. I conclude the section by raising the question of what it might look like for a firm to stand up for, instead of blaming or firing, the employee at the center of mass social media outrage and suggest that this possibility may at least merit further consideration.

\section{Reflections Directed at Those Who Insist on Firing}

Those who insist that businesses should blame the employee through firing in the kinds of cases we have been considering face at least two difficulties to account for. First, many believe that those who have completed prison sentences for committing serious crimes should be permitted to reintegrate into society; some even think we owe it to such persons to help them reintegrate into the workforce. If we do indeed owe it to such persons to help them re-enter the workforce, what do we, as a society, owe to those who were once fired in response to mass social media outrage for comparatively less serious misconduct? Should one instance of wrongdoing of the sort we've been considering make one permanently unemployable? A view that supports termination in the cases we have been considering should offer a response to these questions.

Second, the point about not tolerating racist, sexist, or other unethical conduct cuts both ways. Whatever one may think of the ethics of the woman's tweet in the AIDS-tweet case ("Going to Africa. Hope I don't get AIDS. Just kidding. I'm white!'), many of the responses to her tweet by outraged social media participants were unequivocally appalling:

- "[she] should just kill herself"

- "Somebody HIV(+) must rape this bitch and we will see if her skin color can protect her from AIDS"

- "We'll welcome her with open arms, Just Kidding. Die you racist cunt"

- "Kill this bitch the moment she steps in any African country..."

- "I want her head on a stick"

- "Someone rape her"

- "Good luck finding a new job you cunt"

Others were more explicit in their demands about her employment:

- "This bitch is a straight up racist! Fire her ass!"

- "Fire this cunt."

It is not clear that aligning one's organization with the demands of outraged individuals on social media who would make these sorts of unambiguously sexist remarks and threats is appropriate. These sort of remarks, especially 
when it is a woman at the center of social media outrage, are not uncommon. The woman who was fired in the Dongles Case, in addition to being subjected to various racial slurs, faced similar remarks: “...Let's crucify this cunt," "Cut out her uterus with an xacto knife," "I hope I can find [her], kidnap her, put a torture bag over her head, and shoot a .22 subsonic round right into her fucking skull. Fuck that bitch make her obey" (Ronson 2015a, p. 120). She also had her home address posted to the internet along with a photograph of a decapitated woman with duct tape covering her mouth (Ronson 2015b). Women in a wide range of other cases involving mass social media outrage have been subjected to similar threats and remarks. ${ }^{37}$

So, in the way that it is common wisdom that in many instances one should not capitulate to threats or demands to avoid encouraging repeat instances of demands (or escalations in demands), we might think that firms acquiescing to the demands of outraged social media participants who would subject another to comments of this sort may help sustain or even encourage this very sort of vile behavior.

Suppose one now acknowledges that firing the employee in mass outrage contexts is not necessary and may also be morally inappropriate but still thinks inaction is unacceptable and that the employee should be blamed for the misconduct. That is, suppose a manager thinks blame is all-thingsconsidered justified but wants to blame without firing. Is there a way to do this? Surely, there is.

\section{Blaming Without Firing}

Suppose a business insists on the moral importance of blaming an employee at the center of mass social media outrage in the kinds of cases we have been discussing, but wants to do so without terminating the employee. How could the business do so? While space does not permit a full discussion of this topic, I will briefly discuss some possibilities. ${ }^{38}$ First, a business could issue a statement of condemnation, without coupling the statement with an additional sanction or penalty. For instance, a business might take the kind of response that the president of Boston University took in

\footnotetext{
37 This sort of treatment that women are subjected to online was prominently brought to light by the Gamergate affair in which a few women who spoke out against sexism in the videogame industry were met with mass outrage of this sort; one individual associated with Gamergate faced "graphic threats of rape, murder, and harm to her and her husband [that] included the specific times of day these crimes would occur, what weapons would be used, and [internet participants] even released her private home address [on the internet]" (Scheff and Schorr 2017, p. 252).

38 It is worth noting that merely because these alternative ways of expressing blame are less harsh than blaming through firing, it does not mean that they are insulated from the requirements pertaining to the ethics of blame.
}

response to a tweet- "why is white america so reluctant to identify white college males as a problem population?"-by one of its incoming assistant professors:

...[The professor's] comments are receiving extensive coverage in the media; we are also hearing from alumni, friends, and others about them. Many have expressed the view that some of [the professor's] comments are offensive and/or racist.

At Boston University, we acknowledge [the professor's] right to hold and express her opinions. Our community is composed of faculty, staff, and students who represent widely varying points of view on many sensitive issues.

At the same time, we fully appreciate why many have reacted so strongly to her statements. Boston University does not condone racism or bigotry in any form, and we are committed to maintaining an educational environment that is free from bias, fully inclusive, and open to wide-ranging discussions. We are disappointed and concerned by statements that reduce individuals to stereotypes on the basis of a broad category such as sex, race, or ethnicity. I believe [the professor's] remarks fit this characterization... (Svrluga 2015)

Businesses too might offer such a statement of condemnation, without also firing the employee. While there are complications related to universities being non-profit institutions with unique aims, the point I am making about the ability to express blame without having to also bring along the badness associated with firing is generalizable to business contexts. ${ }^{39}$

That being said, while such a statement of condemnation may be less harsh than firing, managers should recognize that authorizing a press release in response to an employee's action is a decidedly ethical act, not merely a PR decision. When reprimanding an employee, it is generally considered good practice to pull the employee aside and address him/her privately rather than reprimand him/ her in front of peers: failing to do so would humiliate the employee. Yet with press releases in response to social media outrage, the reprimand of the employee is unabashedly public. Managers should not merely consider the PR dimensions of the decision to issue a press release, but should also consider how such a press release can affect the employee and consider whether one act of wrongdoing

\footnotetext{
39 While this is as an example of what a business could do, I do not cite this as an example of how a university ought to respond to such remarks by a professor; one might even think that this sort of response is especially problematic on the part of a university, given the importance of university obligations to help sustain the intellectual independence of its faculty and other such considerations.
} 
justifies a permanent, publicly viewable stain of condemnation on the internet.

Second, even if one thinks that not tolerating the employee's conduct requires a more severe sanction than a statement of condemnation - that for the blame to be effective, it must be coupled with something that will materially harm the employee-this still does not necessitate termination. A business might issue a sanction that falls short of termination, but is still more severe than a statement of condemnation. For example, when an ESPN reporter was caught on video berating an employee at a car towing office and subsequently became the focus of mass outrage, she was put on a 1-week suspension (Scheff and Schorr 2017, p. 114). Businesses have several options available other than termination: the business might demote an employee, pass over the employee for a promotion, place the employee on temporary suspension or leave, move the employee to a different role, cut the employee' salary or bonus, and so on.

While I don't believe these alternative sanctions are required in order for the business to blame an employee nor to show that it does not tolerate certain forms of conduct, they are some ways a business can blame, without having to resort to termination as a blanket response to employee misconduct in mass social media outrage contexts.

\section{Standing Up for the Employee}

Finally, could an organization that purports to respect and value its employees have an obligation to stand up for or protect an employee at the center of mass social media outrage? While the argument in this article cannot withstand the weight of answering this question affirmatively, it seems to be a thesis worth exploring. What might it look like for an employer to stand up for an employee at the center of mass social media outrage? In August 2018, soon after a young Asian-American journalist was appointed to the editorial board of The New York Times (The Times), her earlier social media activity was unearthed, including tweets like the following: "White men are bullshit," "Are white people genetically disposed to burn faster in the sun, thus logically being only fit to live underground like groveling goblins," "Dumbass fucking white people marking up the internet with their opinions like dogs pissing on fire hydrants," and "oh man it's kind of sick how much joy I get out of being cruel to old white men." These tweets generated mass social media outrage, placing significant pressure on The Times to fire her. Instead of firing her, The Times offered the following statement:
We have hired [the journalist] because of the exceptional work she has done covering the internet and technology at a range of respected publications.

Her journalism and the fact that she is a young Asian woman have made her a subject of frequent online harassment. For a period of time she responded to that harassment by imitating the rhetoric of her harassers. She sees now that this approach only served to feed the vitriol that we too often see on social media. She regrets it, and The Times does not condone it.

We had candid conversations with [her] as a part of our thorough vetting process, which included a review of her social media history. She understands that this type of rhetoric is not acceptable at The Times and we are confident that she will be an important voice for the editorial board moving forward.

In making this statement, rather than capitulating to the demands of outraged social media participants, The Times stood behind its employee, and indeed even spoke to some of her virtues and qualifications, without at the same time condoning the content of her tweets.

Firms often expend considerable time and resources to vet an employee during the hiring process; upon hiring, firms also often have an opportunity to build a relationship with the employee in various capacities. We might plausibly think that this better equips firms to appreciate the moral complexity of the employee at the center of mass social media outrage than distant, outraged social media participants who may not have (or be disposed to seek out) a fuller picture of the employee. This more complex picture of the employee is something an employer might draw attention to when standing up for an employee at the center of mass social media outrage.

The woman who was fired in the Dongles case spoke of her former employer as follows: "[My employer] threw me under the bus. I felt betrayed. I felt abandoned. I felt ashamed. I felt rejected. I felt alone" (Ronson 2015a, p. 121). When an employee is the focus of mass social media outrage, he or she is likely to feel a debilitating alienation from his or her community; this is when an employee most needs support and an ally. Perhaps the firm could fulfill this role: rather than offering a condemnatory, moralizing press release, the firm could speak to the employee's virtues that it has come to appreciate during the employee's tenurevirtues that outraged social media participants are poorly positioned to recognize.

\section{Implications and Future Avenues of Research}

The argument I have presented, while structurally simple, has important theoretical and managerial implications. First, even when an employee has done something wrong (and 
there is clear evidence of this fact and the employee has been afforded adequate due process), there are considerations external to this fact that must be considered in the decision to fire. Notably, the fact that firings have the potential to be inappropriate acts of blame in mass outrage contexts has not to date been fully appreciated in employment ethics. In making this argument, I have brought the employment ethics literature into contact with the growing scholarship on the philosophy of blame. I drew attention to a novel dimension of the ethics of blame, the dependence principle, which holds that the appropriateness of an act of blame depends in part on how much others blame. While this article does not amount to a full defense and articulation of the dependence principle, it does illustrate a significant implication of it for employment ethics.

Second, I argued that in firing decisions in mass outrage contexts, a manager's intent in firing may be irrelevant to the question of whether an employee was wrongfully fired. That is, even if the manager saw the firing strictly as a decision concerning PR or profits, and indeed even regretted having to fire the employee, this does not necessarily justify the firing. One implication of this is that theorists must pay more attention to how the context of an act affects the moral status of the act; for example, the context in which a firing takes place can change it from being merely an ordinary firing to also being an act of blame. Attending to issues in philosophy of language concerning the expressive dimensions of actions, and issues in metaphysics concerning action individuation, can help theorists toward this end. If an otherwise ethically inert act takes on a new significance in certain contexts, this can trigger additional moral requirements.

Third, this article can also serve as an example for how recent technological advances might raise new issues in business ethics debates that may seem well worn. I showed how widespread adoption and use of social media makes it worth revisiting certain questions in employment ethics-in particular, questions pertaining to the ethics of firing. Social media allows for large numbers of individuals to come together and subject a person to blame with much greater ease than ever before. When an employee is at the focus of this outrage, I argued that this has ethical implications for firing decisions. Moreover, before social media, these sorts of firing decisions were found in a realm of managerial decisions that remained largely insulated from such external pressures. In short, this article aimed to serve as an example of how it can be theoretically and practically fruitful to return scholarly attention to certain well-trodden topics in light of technological advances, especially given that technology can in some circumstances open up issues that managers may never have encountered in the past.

This article also opens several further questions for scholars to investigate. While there are many empirical questions that remain uninvestigated-such as how customers, suppliers, investors, and partners alter their interactions with a firm that fails to fire an employee who is at the center of mass social media outrage, or whether a firm might be perceived as a bully due to firing the employee in response to mass outrage, in the way that individuals sometimes can be seen as bullies for contributing to mass social media outrage (Sawaoka and Monin 2018)-I will here focus on normative questions.

First, what role should the victim of the employee's wrongdoing (when there is an identifiable victim) play in a manager's decision? If the victim says, "I don't want her to lose her livelihood; I just want an apology," it seems inappropriate, perhaps even disrespectful, to override this request. In criminal trials, whether the victim forgives is often immaterial to whether the criminal is punished, but it does often figure into the severity of the sentencing. While the victim's voice may not always matter when it comes to responding to wrongdoers, perhaps it should matter more than the vicarious outrage of social media participants. A key task for scholars will be to investigate how to take seriously a victim's claims in the context of managerial decision-making with respect to employee wrongdoing.

Second, are firms justified in terminating relationships with customers, suppliers, and partners due to their misconduct that generates mass social media outrage? Developing an account that covers such a wide variety of relationships (and it is not clear that a unified account will emerge) may require engaging with fundamental questions concerning the legitimacy and scope of managerial authority, the nature of relational morality when there is a power asymmetry in the relationship, and the morality of imposing a corporate culture so strict that any ethical transgressions make one a misfit.

Third, if - contrary to what I have argued—one's off-duty misconduct does usually justify blaming through firing in mass social media outrage contexts, should one's off-duty exemplary conduct be considered in decisions pertaining to hiring, promotions, and bonuses? For example, should an employee's off-duty volunteerism and charitable donations be determining factors in decisions about who to promote? These questions turn on deeper issues pertaining to whether the distribution of harms and goods generate asymmetrical (or perhaps even entirely distinct) moral requirements in the manager.

\section{Conclusion}

Widespread adoption of new technologies, especially social media, has altered the ethical landscape. I argued that the fact that a firing would occur in a mass social media outrage context brought about by an employee's off-duty conduct contributes to the firing being an inappropriate act of blame. 
This is so even when the requirements of procedural justice and due process are met. Moreover, the thesis I defended is one that even supporters of employment at-will have reason to take seriously, given that the argument I advanced does not require adopting strong assumptions about the sorts of legal rights or protections employees should (or should not) have. The decision to fire an employee at the center of mass social media outrage is often considered by managers to be laudatory-indeed, firms often take pains to announce such decisions-but it can often be, on the contrary, ethically unjustified.

Acknowledgements For helpful conversation, feedback, or comments, I thank Alan Strudler, Alexander Guerrero, Amy Sepinwall, Brian Berkey, Carson Young, Craig Smith, Derek Parfit, Diana Robertson, Eric Orts, Errol Lord, Gastón de Los Reyes, Jeff McMahan, Jooho Lee, Jordi Vives Gabriel, Kok-Chor Tan, Larry Temkin, Lauren Kaufmann, Matthew Caulfield, Nicolas Cornell, Pierce Randall, Philip Nichols, Richard Shell, Rob Hughes, Shelby Gai, Sonu Bedi, Suneal Bedi, Tae Wan Kim, Thomas Donaldson, Wayne Norman, William Laufer, and audiences at Fordham University's Gabelli School of Business, Rutgers Business School, The Wharton School's Legal Studies and Business Ethics Department, Naval Postgraduate School's Graduate School of Business and Public Policy, Santa Clara University's Leavey School of Business, Cal State University, Sacramento, and the Society for Business Ethics. I am also grateful for helpful comments and feedback from three anonymous reviewers for this journal.

Funding This research was conducted, in part, when receiving support from the Carol and Lawrence Zicklin Center for Business Ethics Research and from the Lewis Platt Fellowship.

\section{Compliance with Ethical Standards}

Conflict of interest The author declares that he has no conflict of interest.

Ethical Approval This article does not contain any studies with human participants or animals performed by the author.

Open Access This article is distributed under the terms of the Creative Commons Attribution 4.0 International License (http://creativeco mmons.org/licenses/by/4.0/), which permits unrestricted use, distribution, and reproduction in any medium, provided you give appropriate credit to the original author(s) and the source, provide a link to the Creative Commons license, and indicate if changes were made.

\section{References}

Allen, D. G., Bryant, P. C., \& Vardaman, J. M. (2010). Retaining talent: Replacing misconceptions with evidence-based strategies. Academy of Management Perspectives, 24(2), 48-64.

Anderson, E. (2017). Private government: How employers rule our lives (and why we don't talk about it). Princeton: Princeton University Press.

Anderson, E. S., \& Pildes, R. H. (2000). Expressive theories of law: A general restatement. University of Pennsylvania Law Review, 148(5), 1503-1575.
Arnold, D. (2006). Corporate moral agency. Midwest Studies in Philosophy, 30(1), 279-291.

Arnold, D. G. (2009). Working conditions: Safety and sweatshops. In G. G. Brenkert (Ed.), The oxford handbook of business ethics. Oxford: Oxford University Press.

Baier, A. C. (1993). Moralism and cruelty: Reflections on Hume and Kant. Ethics, 103(3), 436-457.

Barry, B. (2007a). Speechless: The erosion of free expression in the American workplace. Oakland: Berrett-Koehler Publishers.

Barry, B. (2007b). The cringing and the craven: Freedom of expression in, around, and beyond the workplace. Business Ethics Quarterly, 17(02), 263-296.

Bauer, T. N., Bodner, T., Erdogan, B., Truxillo, D. M., \& Tucker, J. S. (2007). Newcomer adjustment during organizational socialization: a meta-analytic review of antecedents, outcomes, and methods. Journal of Applied Psychology, 92(3), 707.

Bennett, M., Polden, D., \& Ruben, H. (1998). Employment relationships: Law \& practice (LSLF). Silver Spring: Aspen Publishers.

Bhardwaj, P. (2017). Yes, colleges check applicants' social media posts. Consumer Reports. https://www.consumerreports.org/socia 1-media/colleges-check-applicants-social-media-posts/.

Bianchi, E. C., \& Brockner, J. (2012). In the eyes of the beholder? The role of dispositional trust in judgments of procedural and interactional fairness. Organizational Behavior and Human Decision Processes, 118(1), 46-59.

Bies, R. J., \& Shapiro, D. L. (1988). Voice and justification: their influence on procedural fairness judgments. Academy of Management Journal, 31(3), 676-685.

Bobocel, D. R., \& Gosse, L. (2015). Procedural justice: A historical review and critical analysis. In R. S. Cropanzano \& M. L. Ambrose (Eds.), The oxford handbook of justice in the workplace. Oxford: Oxford University Press.

Brennan, J., \& Jaworski, P. M. (2015). Markets without symbolic limits. Ethics, 125(4), 1053-1077.

Brockner, J. (2002). Making sense of procedural fairness: How high procedural fairness can reduce or heighten the influence of outcome favorability. Academy of Management Review, 27(1), 58-76.

Brockner, J., De Cremer, D., van den Bos, K., \& Chen, Y.-R. (2005). The influence of interdependent self-construal on procedural fairness effects. Organizational Behavior and Human Decision Processes, 96(2), 155-167.

Brockner, J., Konovsky, M., Cooper-Schneider, R., Folger, R., Martin, C., et al. (1994). Interactive effects of procedural justice and outcome negativity on victims and survivors of job loss. Academy of Management Journal, 37(2), 397-409.

Caulfield, M. (Forthcoming). Expressive business ethics. In J. Weber \& D. M. Wasieleski (Eds.), Business ethics (business and society 360) (vol. 3). Bingley: Emerald.

Coates, D. J., \& Tognazzini, N. A. (Eds.). (2013). Blame: Its nature and norms. Oxford: Oxford University Press.

Cohen, G. (2006). Casting the first stone: Who can, and who can't, condemn the terrorists? Royal Institute of Philosophy Supplement, $58,113-136$.

Coine, T., \& Babbitt, M. (2014). A world gone social: How companies must adapt to survive. New York: AMACOM.

De Cremer, D., Brockner, J., Fishman, A., van Dijke, M., van Olffen, W., et al. (2010). When do procedural fairness and outcome fairness interact to influence employees' work attitudes and behaviors? The moderating effect of uncertainty. Journal of Applied Psychology, 95(2), 291-304.

DeWall, C. N., MacDonald, G., Webster, G. D., Masten, C. L., Baumeister, R. F., et al. (2010). Acetaminophen reduces social pain: Behavioral and neural evidence. Psychological Science, 21(7), 931-937.

Diaz, J., \& Effron, L. (2015). Former CFO on food stamps after controversial viral video about Chick-Fil-A. ABC News. http://abcne 
ws.go.com/Business/cfo-food-stamps-controversial-viral-video/ story? $\mathrm{id}=29533695$.

Donaldson, T. (1980). Moral agency and corporations. Philosophy in Context, 10, 54-70.

Donner, F. (2011). The workplace whodunit: Navigating a culture of blame. Wall Street Journal. https://www.wsj.com/articles/SB100 01424052748703421204576331633789273362.

Dube, A., Freeman, E., \& Reich, M. (2010). Employee replacement costs. Institute for Research on Labor and Employment.

Dyches, C. (2017). 'Can you spell deportation?' McDonald's employee fired after encounter caught on video. WBTV.com. http://www. wbtv.com/story/36350355/can-you-spell-deportation-mcdonaldsemployee-fired-after-encounter-caught-on-video.

Eisenberger, N. I., \& Lieberman, M. D. (2004). Why rejection hurts: A common neural alarm system for physical and social pain. Trends in Cognitive Sciences, 8(7), 294-300.

Epstein, R. A. (1984). In defense of the contract at will. The University of Chicago Law Review, 51(4), 947-982.

Fast, N. J. (2010). How to stop the blame game. Harvard Business Review. https://hbr.org/2010/05/how-to-stop-the-blame-game.

French, P. A. (1979). The corporation as a moral person. American Philosophical Quarterly, 16(3), 207-215.

Fricker, M. (2016). What's the point of blame? A paradigm based explanation. Noûs, 50(1), 165-183.

Friedman, M. (2013). How to blame people responsibly. Journal of Value Inquiry, 47(3), 271-284.

Fritz, K. G., \& Miller, D. (2018). Hypocrisy and the standing to blame. Pacific Philosophical Quarterly, 99(1), 118-139.

Gibbard, A. (1992). Wise choices, apt feelings: A theory of normative judgment. Cambridge: Harvard University Press.

Grice, H. P. (1989). Logic and conversation. In P. Grice (Ed.), Studies in the way of words. Cambridge: Harvard University Press.

Grierson, J., \& Quinn, B. (2018). Google loses landmark "right to be forgotten" case. The Guardian. https://www.theguardian.com/ technology/2018/apr/13/google-loses-right-to-be-forgotten-case.

Hasnas, J. (2012). Reflections on corporate moral responsibility and the problem solving technique of Alexander the Great. Journal of Business Ethics, 107(2), 183-195.

Hess, K. (2014). The free will of corporations (and other collectives). Philosophical Studies, 168(1), 241-260.

Hieronymi, P. (2004). The force and fairness of blame. Philosophical Perspectives, 18(1), 115-148.

Hill, M., \& Wright, J. A. (1993). Employee lifestyle and off-duty conduct regulation. Washington: Bna Books.

Husak, D. N. (1990). Already punished enough. Philosophical Topics, 18(1), 79-99.

Husak, D. N. (1992). Why punish the deserving. Noûs, 26(4), 447-464.

Langston, G. (2012). Dating games for 2012. eHarmony blog. https://www. eharmony.com/blog/the-dating-games-of-2012/\#.W6fe-hNKiL8.

Lerner, M. J. (1980). The belief in a just world: A fundamental delusion. New York: Plenum Press.

List, C., \& Pettit, P. (2011). Group agency: The possibility, design and status of group agents. Oxford: Oxford University Press.

Lupton, B., \& Warren, R. (2018). Managing without blame? Insights from the philosophy of blame. Journal of Business Ethics, 152(1), $41-52$.

Maitland, I. (1989). Rights in the workplace: A Nozickian argument. Journal of Business Ethics, 8(12), 951-954.

Man fired for applauding Vancouver riot on Facebook. (2011). CTV News Vancouver. https://bc.ctvnews.ca/man-fired-for-applauding -vancouver-riot-on-facebook-1.659032.

McCall, J. J. (2003). A defense of just cause dismissal rules. Business Ethics Quarterly, 13(02), 151-175.

McCall, J. J., \& Werhane, P. H. (2009). Employment at will and employee rights. In G. G. Brenkert (Ed.), The oxford handbook of business ethics. Oxford: Oxford University Press.
McGeer, V. (2013). Civilizing blame. In D. J. Coates \& N. A. Tognazzini (Eds.), Blame: Its nature and norms. New York: Oxford University Press.

McKenna, M. (2013). Directed blame and conversation. In D. J. Coates $\&$ N. A. Tognazzini (Eds.), Blame: Its nature and norms. New York: Oxford University Press.

McMahon, C. (1995). The ontological and moral status of organizations. Busines Ethics Quarterly, 5(3), 541-554.

Moore, A. D. (2000). Employee monitoring and computer technology: Evaluative surveillance v. privacy. Business Ethics Quarterly, 10(3), 697-709.

Otto, J., \& Sapa. (2013). Racist aids tweet: I am ashamed. Independent Online. https://www.iol.co.za/news/south-africa/western-cape/ racist-aids-tweet-i-am-ashamed-1625863.

Parfit, D. (1984). Reasons and persons. Oxford: Oxford University Press.

Pereboom, D. (2006). Living without free will. Cambridge: Cambridge University Press.

Pereboom, D. (2014). Free will, agency, and meaning in life. Oxford: Oxford University Press.

Pettit, P. (2007). Responsibility incorporated. Ethics, 117(2), 171-201.

Priest, M. (2016). Blame after forgiveness. Ethical Theory and Moral Practice, 19(3), 619-633.

Radin, T. J., \& Werhane, P. H. (1996). The public/private distinction and the political status of employment. American Business Law Journal, 34(2), 245-260.

Radzik, L. (2011). On minding your own business: Differentiating accountability relations within the moral community. Social Theory and Practice, 37(4), 574-598.

Radzik, L. (2014). Moral rebukes and social avoidance. Journal of Value Inquiry, 48(4), 643-661.

Radzik, L. (2016). Gossip and social punishment. Res Philosophica, 93(1), 185-204.

Ronson, J. (2015a). So you've been publicly shamed. London: Picador.

Ronson, J. (2015b). How one stupid tweet blew up justine sacco's life. The New York Times Magazine. https://www.nytim es.com/2015/02/15/magazine/how-one-stupid-tweet-ruined-justi ne-saccos-life.html.

Root, T., \& McKay, S. (2014). Student awareness of the use of social media screening by prospective employers. Journal of Education for Business, 89(4), 202-206.

Rosen, G. (2002). Culpability and ignorance. Proceedings of the Aristotelian Society, 103(1), 61-84

Rosen, G. (2004). Skepticism about moral responsibility. Philosophical Perspectives, 18(1), 295-313.

Sawaoka, T., \& Monin, B. (2018). The paradox of viral outrage. Psychological Science, 29(10), 1665-1678.

Scanlon, T. (2008). Moral dimensions: Permissibility, meaning, blame. Cambridge: Belknap Press of Harvard University Press.

Scanlon, T. M. (1977). Due process. In J. R. Pennock \& J. W. Chapman (Eds.), Due process: Nomos XVIII. New York: New York University.

Scheff, S., \& Schorr, M. (2017). Shame nation: The global epidemic of online hate. Naperville: Sourcebooks, Inc.

Sepinwall, A. (2016). Corporate moral responsibility. Philosophy Compass, 11(1), 3-13.

Sher, G. (2006). In praise of blame. New York: Oxford University Press.

Sherman, E. (2014). Blaming others: The slow way to kill your business. Inc. https://www.inc.com/erik-sherman/take-the-blame-andbetter-your-business.html.

Smilansky, S. (2006). The paradox of moral complaint. Utilitas, 18(03), 284-290.

Smith, A. (2007). On being responsible and holding responsible. The Journal of Ethics, 11(4), 465-484. 
Strawson, P. F. (1962). Freedom and resentment. Proceedings of the British Academy, 48, 1-25.

Sugarman, S. D. (2003). "Lifestyle" discrimination in employment. Berkeley Journal of Employment and Labor Law, 24(2), 377-438.

Svrluga, S. (2015). Critics claim Boston University is racist, but they don't agree if it's anti-black or anti-white. The Washington Post. https://www.washingtonpost.com/news/grade-point/ $\mathrm{wp} / 2015 / 05 / 12 /$ critics-say-boston-university-has-a-race-probl em-but-dont-agree-whether-its-anti-black-or-anti-white/?utm term $=.2 \mathrm{df} 3 \mathrm{f} 3471273$.

Todd, P. (2017). A unified account of the moral standing to blame. Noûs. https://doi.org/10.1111/nous.12215.

Tosi, J., \& Warmke, B. (2016). Moral grandstanding. Philosophy \& Public Affairs, 44(3), 197-217.

Tune, J. K. (2013). Breaking: Adria Richards fired by SendGrid for calling out developers on Twitter. Venture Beat. https://venturebea t.com/2013/03/21/breaking-adria-richards-fired-by-sendgrid-foroutting-developers-on-twitter.

Velasquez, M. (2003). Debunking corporate moral responsibility. Business Ethics Quarterly, 13(4), 531-562.

Velasquez, M. G. (1983). Why corporations are not morally responsible for anything they do. Business \& Professional Ethics Journal, 2(3), $1-18$

Wakabayashi, D. (2017). Google fires engineer who wrote memo questioning women in tech. New York Times. https://www.nytim es.com/2017/08/07/business/google-women-engineer-fired -memo.html.

Wallace, R. J. (1994). Responsibility and the moral sentiments. Cambridge: Harvard University Press.

Wallace, R. J. (2010). Hypocrisy, moral address, and the equal standing of persons. Philosophy and Public Affairs, 38(4), 307-341.

Wallace, R. J. (2011). Dispassionate opprobrium: On blame and the reactive sentiments. In R. J. Wallace, R. Kumar, \& S. Freeman (Eds.) Reasons and recognition: Essays on the philosophy of T.M. Scanlon. Oxford: Oxford University Press.

Watson, G. (2013). Standing in judgment. In G. Watson, D. J. Coates \& N. A. Tognazzini (Eds.), Blame: Its nature and norms. New York: Oxford University Press.

Werhane, P., \& Freeman, R. E. (2003). Corporate responsibility. In H. Lafollette (Ed.), The oxford handbook of practical ethics. Oxford: Oxford University Press.

Werhane, P. H. (1999). Justice and trust. Journal of Business Ethics, 21(2-3), 237-249.

Werhane, P., \& Radin, T. J. (1999). Employment at will and due process. In T. Beauchamp \& N. Bowie (Eds.), Ethical theory and business (6th edn). Upper Saddle River: Prentice Hall.

Werhane, P., Radin, T. J., \& Bowie, N. E. (2008). Employment and employee rights. New York: Wiley. 